\title{
Reproducing Botryosphaeria Dieback Foliar Symptoms in a Simple Model System
}

\begin{abstract}
Pedro Reis, Centro de Investigação em Agronomia, Alimentos, Ambiente e Paisagem (LEAF), Instituto Superior de Agronomia, Universidade de Lisboa, Tapada da Ajuda, 1349-017 Lisbon, Portugal; Maryline Magnin-Robert, SFR Condorcet, Université de Reims ChampagneArdenne, URVVC EA 4707, Laboratoire Stress Défenses et Reproduction des Plantes, Moulin de la Housse, BP 1039, 51687 Reims Cedex 2, France; Teresa Nascimento, Departamento de Ciências e Engenharia de Biossistemas, Instituto Superior de Agronomia, Universidade de Lisboa; Alessandro Spagnolo, SFR Condorcet, Université de Reims Champagne-Ardenne, URVVC EA 4707, Laboratoire Stress Défenses et Reproduction des Plantes; Eliane Abou-Mansour, Université de Fribourg, Département biologie végétale, 10 chemin du musée, 1700 Fribourg, Switzerland; Cristina Fioretti and Christophe Clément, SFR Condorcet, Université de Reims Champagne-Ardenne, URVVC EA 4707, Laboratoire Stress Défenses et Reproduction des Plantes; Cecilia Rego, LEAF, Instituto Superior de Agronomia, Universidade de Lisboa; and Florence Fontaine, SFR Condorcet, Université de Reims Champagne-Ardenne, URVVC EA 4707, Laboratoire Stress Défenses et Reproduction des Plantes
\end{abstract}

\begin{abstract}
Reis, P., Magnin-Robert, M., Nascimento, T., Spagnolo, A., Abou-Mansour, E., Fioretti, C., Clément, C., Rego, C., and Fontaine, F. 2016. Reproducing Botryosphaeria dieback foliar symptoms in a simple model system. Plant Dis. 100:1071-1079.

Botryosphaeria dieback is a grapevine trunk disease with a worldwide distribution associated with Diplodia seriata and Neofusicoccum parvum, among several other Botryosphaeriaceae species. The aforementioned xylem-inhabiting fungi cause wood lesions and leaf and berry symptoms, and eventually lead to the death of the plant. The aim of this work was to develop a simple model system to reproduce the foliar symptoms caused by $D$. seriata and $N$. parvum to better characterize fungal pathogenicity and determine the mechanisms involved in symptom development. Green stems of grafted 'Aragonez' grapevine cuttings were inoculated with three isolates of $N$. parvum and two isolates of $D$. seriata with different degrees of virulence and the experiment was repeated four times from 2011 to 2014. Three

months after inoculation, the lesions associated with $N$. parvum were larger than those associated with $D$. seriata. Similarly, 8 months after inoculation, the percentage of plants showing foliar symptoms was greater in the $N$. parvum treatments than in the $D$. seriata treatments. During the emergence of foliar symptoms, plant stress-related responses were modulated in green stems and leaves, especially a downregulation of superoxide dismutase $(S O D)$ and fasciclin-like arabinogalactan protein ( $f a s c A G P)$ and an upregulation of stilbene synthase (STS) genes with an accumulation of phenolics. In conclusion, the simple model system developed allowed a good characterization of isolate pathogenicity and correlation with foliar symptoms of Botryosphaeria dieback, namely spots on leaf margin and blade.
\end{abstract}

Several Botryosphaeriaceae species are associated worldwide with the grapevine trunk diseases (GTD) known as Botryosphaeria dieback (Fischer 2006; Graniti et al. 2000; Larignon and Dubos 1997; Larignon et al. 2009, 2015; Moller and Kasimatis 1978; Spagnolo et al. 2014a; Úrbez-Torres 2011). The most common species isolated from grapevine-growing regions around the world include Diplodia seriata De Not. (Castillo-Pando et al. 2001; Cristinzio 1978; Larignon et al. 2001; Phillips et al. 2007; Rovesti and Montermini 1987; Savocchia et al. 2007; Úrbez-Torres et al. 2008) and Neofusicoccum parvum (Pennycook \& Samuels) Crous, Slippers \& A. J. L. Phillips (Crous et al. 2006). These fungi are xylem inhabiting and attack the framework of grapevines, causing perennial cankers in the wood, resulting in leaf and berry symptoms, and, finally, leading to the death of the plant. Symptoms are characterized by yellowish-orange (white cultivars) or wine-red (red cultivars) spots on leaf margins and blades and, in most cases, the emergence of a brown stripe on the wood under the bark (Larignon et al. 2001; Spagnolo et al. 2014a). This symptom is often associated with a gray sector of rotted wood. Shriveling and drying of inflorescences or fruit clusters are frequently observed.

Corresponding author: F. Fontaine; E-mail: florence.fontaine@univ-reims.fr

C. Rego and F. Fontaine participated equally in this work.

*The $\boldsymbol{e}$-Xtra logo stands for "electronic extra" and indicates that one supplementary figure is published online.

Accepted for publication 23 January 2016.

http://dx.doi.org/10.1094/PDIS-10-15-1194-RE

(C) 2016 The American Phytopathological Society
The incidence of Botryosphaeria dieback, together with two other trunk diseases (esca and Eutypa dieback), has increased over the years. In France, it was estimated that $13 \%$ of productive vines were affected by GTD in 2012 (Bruez et al. 2013; Grosman and Doublet 2012). Although GTD, including Botryosphaeria dieback, appear to be increasingly common, accurate knowledge of host-pathogen interactions poses certain problems, including (i) determining the seasonal influence on field-collected data due to an uncontrolled environment and (ii) distinguishing pathogen effects on grapevines from effects in response to other biotic agents in the field. Research has been developed to gain a better understanding of the mechanisms that are involved in symptom expression by the artificial reproduction of the symptoms through individual or combined inoculations of pathogenic fungi or by the use of simpler grapevine model systems (e.g., cuttings, grapevine in vitro plants, or grapevine cultured cells) under controlled conditions. Regarding Eutypa dieback symptoms, the stunting of new shoots, with small, cup-shaped, chlorotic and tattered leaves, was reproduced on greenhouse cuttings that were infected with Eutypa lata ascospores or mycelial plugs (Péros and Berger 1994, 1999; Petzoldt et al. 1981; Sosnowski et al. 2007). For esca disease, pathogenicity tests were carried out in a greenhouse with vines inoculated with Phaeomoniella chlamydospora (Chiarappa 2000). Although a significant reduction of growth was observed, typical foliar symptoms were not reproduced. With $P$. chlamydospora, similar results were obtained with inoculated cuttings, as reported by Gerbore (2013) and Pierron et al. (2015). For Botryosphaeria dieback, no studies have been reported on the development of such model systems, both necrosis and foliar symptom development, for the analysis of pathogenicity.

Data crossing of plant response and fungal activity in compatible interactions could yield important information about the mechanisms developed by fungi to colonize grapevine and the protective response of the grapevine to limit the development of the fungi. The difficulties of such work could arise from the fact that the grapevine 
is a perennial plant cultivated worldwide under various environmental conditions. The development of a simple model system for the inoculation of grapevine plants under controlled conditions to optimize and validate disease development is required. With such a tool, knowledge of the interactions between the GTD agents could progress and such a model system could represent a first step toward the development of management solutions against these diseases because the visual presence of symptoms in leaves leads to an early diagnostic. The aim of this work was to develop a simple model system using D. seriata and $N$. parvum to better characterize their virulence by measuring the size of lesions and evaluating the percentage of vines developing foliar symptoms and, thereby, understand their impact on vine physiology by studying the stress response at a molecular level and by quantification of phenolic compounds.

\section{Materials and Methods}

Plant material and fungal inoculation. Each year, during a 4-year period (2011 to 2014), 1-year-old grafted 'Aragonez' (= 'Tempranillo') grapevine cuttings were potted individually in a 1-liter, free-draining bag containing a sandy soil mixture (one-third sand, one-third soil, and one-third organic matter) and placed using a completely randomized design in a ventilated greenhouse at $24^{\circ} \mathrm{C}$ under natural light. After 1 month of growth, plants were inoculated with isolates of $N$. parvum and $D$. seriata with two different origins (Portuguese, isolated by C. Rego, and French, isolated by P. Larignon) and different degrees of aggressiveness (Larignon et al. 2001; Rego et al. 2009) (Table 1). A 3-mm area of the bark was removed with a cork borer from the base of the primary stems (approximately $1.5 \mathrm{~cm}$ in diameter) between the second and third nodes. The wounds were inoculated with 3-mm mycelial plugs taken from the actively growing margin of 8-day-old colonies of $N$. parvum and $D$. seriata growing on potato dextrose agar (PDA; Difco, BD) at $24^{\circ} \mathrm{C}$ in darkness. Each inoculation point was covered with moist cotton wool and sealed with Parafilm. In 2014, the causal agent of black rot of vine Phyllosticta ampelicida (Engelm.) Aa (isolates Gb 32 and Gb 17), Cladosporium sp., and Penicillium sp. isolates (Table 1) were also inoculated in the same manner as positive controls to determine whether the expression of foliar symptoms was specific to both $N$. parvum and D. seriata. Negative controls were inoculated using the same method but with sterile 3-mm PDA plugs to confirm that lesions were due to infection by the pathogens and not to the wounding. There were 30 replicates for each treatment and the experiment was kept in the same greenhouse to observe foliar symptom emergence 8 months after inoculation.

Determination of lesion size, symptom appearance, and isolation of pathogens. The dimension of lesions was evaluated 3 months after inoculation on green shoots, before lignification occurred, by measuring the width and the length and calculating the elliptical area of the lesion. All statistical analyses were performed using STATISTICA (version 8.0, 2007; StatSoft, Inc.). Homogeneity of variance was tested using Levene's test. Residuals were visually inspected for each experiment and, when necessary, the $\log _{10}$ transformation was used to improve homogeneity of variance. One-way analysis of variance was used to compare differences in mean lesions (width, length, and area of discoloration) among fungal isolates and species. Means were separated using Tukey's test at the 5\% significance level. Percentage of grapevines in each treatment that showed foliar symptoms was visually inspected. When one or more leaves expressed spots or chlorotic areas, the plant was considered positive for expression of foliar symptoms. Data collected from each trial were subjected to $\chi^{2}$ statistical analysis $\left(\chi^{2}\right.$ test $)$ at the $5 \%$ significance level. Treatment means were compared using Tukey's test at the 5\% significance level. Percentages were transformed to arcsine square-root values before analysis.

In order to fulfill Koch's postulates, small pieces of necrotic tissue from the edge of each lesion were cut and placed on PDA medium amended with chloramphenicol (BioChemica; AppliChem) at $250 \mathrm{mg} \mathrm{liter}^{-1}$ to recover the inoculated fungi.

Plant RNA extraction. When foliar symptoms first appeared, symptomatic and asymptomatic leaves and stems were collected in 2012 from symptomatic and asymptomatic plants, respectively, immediately wrapped in aluminum foil, frozen in liquid nitrogen, and stored at $-80^{\circ} \mathrm{C}$. Samples were ground in liquid nitrogen to a fine powder. Plant RNA Purification Reagent (Invitrogen) was used to isolate total RNA from $1 \times 50 \mathrm{mg}$ of leaf tissue powder and $2 \times$ $50 \mathrm{mg}$ of green stem powder. The RNA pellet was resuspended in $20 \mu \mathrm{l}$ of RNase-free water and treated with RQ1 DNase enzyme (Promega), and RNA was quantified by measuring the absorbance at $260 \mathrm{~nm}$, according to the manufacturer's instructions, and stored at $-80^{\circ} \mathrm{C}$ before use.

Real-time reverse-transcription polymerase chain reaction analysis of gene expression. In all, $150 \mathrm{ng}$ of total RNA was reverse-transcribed using the Verso SYBR 2-step QRT ROX enzyme (ABgene), according to the manufacturer's protocol. polymerase chain reaction (PCR) conditions were as described by Bézier et al. (2002). Gene expression was tracked by quantitative reversetranscription (RT)-PCR using the primers reported in Table 2. The 14 genes studied were previously selected from a proteomic study (Spagnolo et al. 2012) focused on grapevine reactions in response to trunk diseases: 6 genes involved in detoxification and stress tolerance (haloacid dehalogenase hydrolase $[\mathrm{Hahl}]$, epoxide hydrolase [epox]HF, glutathione-S-transferase [GST]5, superoxide dismutase $[S O D], \alpha$-crystalline small heat-shock protein $[H S P]$, and epoxH2), 1 gene involved in terpenoid synthesis (DXS1), 2 genes encoding for pathogenesis-related (PR) protein, 1 gene involved in wall cell compound synthesis (fasciclin-like arabinogalactan protein [fascAGP]), 1 gene encoding for an aquaporin plasma membrane intrinsic protein 2-2 (PIP2.2), and the 3 last genes involved in the phenylpropanoid pathway (stilbene synthase [STS], polyphenoloxidase $[P P O]$, and laccase 17-like [ $\mathrm{Lacl7}$ ]) (Table 2). Two housekeeping genes were used as the internal standard to normalize the starting template of cDNA for each matrix (for leaves: $\alpha$-chain elongation factor 1 gene $[E F 1-\alpha]$ and 39S ribosomal protein L41-A [39SRP]; for green stem: $E F 1-\alpha$ and 60S ribosomal protein L18 [60SRP]). Reactions were carried out in a real-time PCR detector Chromo 4 apparatus (Bio-Rad) using the following thermal profile: $15 \mathrm{~s}$ at $95^{\circ} \mathrm{C}$ (denaturation) and $1 \mathrm{~min}$ at $60^{\circ} \mathrm{C}$ (annealing or extension) for 40 cycles. Melting curve assays were performed from 65 to $95^{\circ} \mathrm{C}$ at $0.5^{\circ} \mathrm{C} \mathrm{s} s^{-1}$. Melting peaks were visualized to check the specificity of each amplification. Results correspond to the means of the independent experiments that were expressed relative to the control corresponding to a fixed

Table 1. Isolates of Neofusicoccum parvum, Diplodia seriata, Phyllosticta ampelicida, a Penicillium sp., and a Cladosporium sp. used for inoculation

\begin{tabular}{llll}
\hline Strain & \multicolumn{1}{c}{ Species } & Aggressiveness $^{\mathbf{z}}$ & \multicolumn{1}{c}{ Origin $^{-}$} \\
\hline Neofusicoccum parvum 19 & N. parvum & High & Portugal \\
N. parvum 67 & N. parvum & Low & Portugal \\
Diplodia seriata $98-1$ & D. seriata & High & France \\
D. seriata $99-7$ & D. seriata & Low & France \\
N. parvum AR & N. parvum & nd & France \\
Gb 17 & Phyllosticta ampelicida & Medium & Portugal \\
Gb 32 & P. ampelicida & High & Portugal \\
$\ldots$ & Penicillium sp. & Not pathogenic & France \\
$\ldots$ & Cladosporium sp. & Not pathogenic & France \\
\hline
\end{tabular}

\footnotetext{
${ }^{\mathrm{z}}$ Abbreviation: $\mathrm{nd}=$ not determined.
} 
value of 1. Control samples consisted of noninoculated plants. The genes analyzed were considered significantly up- or downregulated when changes in their expression was $>2 \times$ or $<0.5 \times$, respectively.

Extraction and quantification of phenolic compounds. The protocol used is described by Spagnolo et al. (2014b). Briefly, methanolic extracts were prepared from $50 \mathrm{mg}$ of powdered leaf and green stem tissues mixed with $1 \mathrm{ml}$ of methanol and $25 \mu \mathrm{l}$ of the internal standard trans-4-hydroxystilbene $\left(0.5 \mathrm{mg} \mathrm{ml}^{-1}\right)$. For quantitative analysis of stilbenes, $60 \mu \mathrm{l}$ of methanolic extract was analyzed by high-performance liquid chromatography. Standards such as transpiceid, transresveratrol, and transpterostilbene (Supplementary Fig. S1) were purchased from Extrasynthèse. The transe-viniferin, transvitisin A, and transvitisin B were obtained from lignified 'Syrah' canes, as described by Spagnolo et al. (2014b). Spectral data for all peaks were accumulated in the range between 220 and $600 \mathrm{~nm}$. The data are reported as micrograms per gram of fresh weight, with a standard deviation from three independent extractions and analyses. To determine whether concentration of control plants were significantly different from the inoculated plants, a Dunn's Multiple Comparison Test was used. Differences at $P \leq 0.05$ were considered significant.

\section{Results}

Observation of lesion and foliar symptom expression on plants inoculated with $N$. parvum and $D$. seriata. For each year and for each isolate, 30 grafted vines growing under greenhouse conditions were inoculated individually with $N$. parvum fungal isolates $\mathrm{AR}$,
19, and 67 and D. seriata isolates 98-1 and 99-7. Control grafted vines were maintained under the same greenhouse conditions. At 3 months after inoculation, dark-brown lesions developed on green stems for all the inoculated isolates (Fig. 1) and their size was evaluated in terms of width, length, and surface area (Table 3). V-shaped cankers were also observed when cross sections were made on symptomatic canes. For the 4 years of repetitions, mean lesion widths associated with $D$. seriata $98-1,99-7$, and $N$. parvum AR infection were slightly lower than those associated with $N$. parvum 19 and 67. Mean lesion lengths associated with $N$. parvum 67 and AR were higher than those for D. seriata 98-1 and 99-7 and N. parvum 19. Thus, the mean lesion surface areas associated with $N$. parvum 67 and AR were greater than those associated with D. seriata 98-1 and 99-7 and $N$. parvum 19 (Table 3 ). Each year, 8 months after inoculation, foliar symptoms appeared in some of the 30 infected grapevines per isolate. These were characterized by typical orange or red spots at the margins of the leaf and large chlorotic areas between veins (Fig. 2). Plants were visually evaluated and the percentage of infected plants showing foliar symptoms was greater for N. parvum 67 and 19 (for example, $73.3 \%$ in 2014) than for D. seriata 98-1, 99-7, and $N$. parvum AR, with values of 50.0, 30.0 , and $60.0 \%$, respectively. None of the 30 control plants showed symptoms (Table 4). The positive control assay revealed that both $\mathrm{Gb}$ 17 and $\mathrm{Gb} 32$ produced lesions on green stems but no foliar symptoms were observed, while Cladosporium and Penicillium spp. gave rise to small necroses similar to those recorded for the negative

Table 2. Primers of genes analyzed by real-time reverse-transcription polymerase chain reaction

\begin{tabular}{|c|c|c|c|}
\hline Genes & Primer sequences & $\begin{array}{l}\text { GenBank or TC TIGR } \\
\text { accession number }\end{array}$ & Matrix \\
\hline \multirow{2}{*}{$\begin{array}{l}E F 1-\alpha \text { (elongation factor } 1-\alpha, \text { housekeeping } \\
\text { gene) }\end{array}$} & 5'-GAACTGGGTGCTTGATAGGC-3' & GU585871 & Leaf \\
\hline & 5'-AACCAAAATATCCGGAGTAAAAGA-3' & $\ldots$ & Green stem \\
\hline \multirow{2}{*}{$\begin{array}{l}\text { 39SRP (39S ribosomal protein L41-A, } \\
\text { housekeeping gene) }\end{array}$} & 5'-GACTGACTTCAAGCTTAAACC-3' & XM_002285709 & Leaf \\
\hline & 5'-GATATAACAGGGAATACAGCAC-3' & . & $\cdots$ \\
\hline \multirow{2}{*}{$\begin{array}{l}\text { 60SRP (60S ribosomal protein } L 18, \\
\text { housekeeping gene) }\end{array}$} & 5'-ATCTACCTCAAGCTCCTAGTC-3' & XM_002270599 & Green stem \\
\hline & 5'-CAATCTTGTCCTCCTTTCCT-3' & $\ldots$ & .. \\
\hline \multirow[t]{2}{*}{ Hahl (haloacid dehalogenase hydrolase) } & 5'-CCCTCAGGATAGCCAACATCA-3' & XM_002267523 & Leaf \\
\hline & 5'-AGGTGCCAACCAGAACTGTGT-3' & $\ldots$ & Green stem \\
\hline \multirow[t]{2}{*}{ epoxH2 (epoxide hydrolase 2) } & 5'-TCTGGATTCCGAACTGCATTG-3' & XM_002270484 & Green stem \\
\hline & 5'-ACCCATGATTAGCAGCATTGG-3' & $\ldots$ & $\ldots$ \\
\hline \multirow[t]{2}{*}{ epoxHF (epoxide hydrolase) } & 5'-TGCTCGTCTTGGCACTGAGA-3' & XM_003632333 & Leaf \\
\hline & 5'-TGAGCGCACCACTGTACCAT-3' & $\ldots$ & $\ldots$ \\
\hline \multirow[t]{2}{*}{ GST5 (glutathione-S-transferase 5) } & 5'-GCAGAAGCTGCCAGTGAAATT-3' & XM_002277883 & Leaf \\
\hline & 5'-GGCAAGCCATGAAAGTGACA-3' & $\ldots$ & Green stem \\
\hline \multirow[t]{2}{*}{ SOD (superoxide dismutase) } & 5'-GTGGACCTAATGCAGTGATTGGA-3' & AF056622 & Leaf \\
\hline & 5'-TGCCAGTGGTAAGGCTAAGTTCA-3' & $\ldots$ & Green stem \\
\hline \multirow[t]{2}{*}{ HSP ( $\alpha$ crystalline heat shock protein) } & 5'-TCGGTGGAGGATGACTTGCT-3' & XM_002272382 & Leaf \\
\hline & 5'-CGTGTGCTGTACGAGCTGAAG-3' & $\cdots$ & Green stem \\
\hline \multirow[t]{2}{*}{ DXS1 (1-deoxy-d-xylulose-5-phosphate) } & 5'-GCAGAAGCTGCCAGTGAAATT-3' & XM_002277883 & Leaf \\
\hline & 5'-GGCAAGCCATGAAAGTGACA-3' & & \\
\hline \multirow[t]{2}{*}{ PR6 (serine proteinase inhibitor) } & 5'-AGGGAACAATCGTTACCCAAG-3' & AY156047 & Leaf \\
\hline & 5'-CCGATGGTAGGGACACTGAT-3' & . & 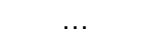 \\
\hline \multirow{2}{*}{ Gluc (glucanase) } & 5'-TCAATGGCTGCAATGGTGC-3' & AF 239617 & Leaf \\
\hline & 5'-CGGTCGATGTTGCGAGATTTA & $\ldots$ & Green stem \\
\hline \multirow{2}{*}{$\begin{array}{l}\text { fascAGP (fasciclin-like arabinogalactan } \\
\text { protein) }\end{array}$} & 5'-CGAAACCCCAAAGCCTAAGAA-3' & XM_002280793 & Green stem \\
\hline & 5'-GAAAACACAAAGGGGTTGCA-3' & $\ldots$ & $\cdots$ \\
\hline \multirow{2}{*}{$\begin{array}{l}\text { PIP2.2 (aquaporin plasma membrane } \\
\text { intrinsic protein } 2-2 \text { ) }\end{array}$} & 5'-GGTTCAGTCTCCATTGCACATG-3' & XM_002271336 & Leaf \\
\hline & 5'-TTGGCAGCACAGCAGATGTAT-3' & $\ldots$ & Green stem \\
\hline \multirow[t]{2}{*}{ Lac17 (laccase like 17) } & 5'-GGACCCAATGGGACAAAGTTT-3' & XM_002284437 & Leaf \\
\hline & 5'-CCATTTGATTGCCCAGAGAAG-3' & $\cdots$ & $\ldots$ \\
\hline \multirow[t]{2}{*}{ STS (stilbene synthase) } & 5'-AGGAAGCAGCATTGAAGGCTC-3' & X76892 & Green stem \\
\hline & 5'-TGCACCAGGCATTTCTACACC-3' & $\ldots$ & $\cdots$ \\
\hline \multirow[t]{2}{*}{ PPO (polyphenol oxidase) } & 5'-TGGTCTTGCTGATAAGCCTAGTGA-3' & XM_002727606 & Green stem \\
\hline & 5'-TCCACATCCGATCGACATTG-3' & $\ldots$ & $\ldots$ \\
\hline
\end{tabular}


controls, and foliar symptoms were absent (Table 5). Reisolation of D. seriata, $N$. parvum, and $\mathrm{Gb}$ isolates was always higher than $70 \%$. No $N$. parvum and D. seriata strains were reisolated from either the Cladosporium and Penicillium spp. inoculations or from the controls.

Stress-related responses in stems and leaves of symptomatic plants inoculated with $N$. parvum and $D$. seriata. The expression of selected stress-related genes was monitored in organs of symptomatic plants to determine whether there was a correlation between the severity of symptoms (lesions and foliar symptoms) and the stress induced in plants in response to fungal inoculation. Results of the gene expression analysis in leaves and green stems are summarized in
Figure 3. The genes considered were grouped in different functional categories according to the organ studied.

Concerning the genes involved in detoxification and stress tolerance, no changes in gene expression were observed for GST5 and both epoxHF and epoxH2 in plant tissues under our conditions (Figs. 3 and 4). A slight downregulation of Hahl was observed in all inoculated plants regardless of the fungal species (Fig. 3). The expression of $S O D$ was weakly repressed in asymptomatic (AP) and symptomatic leaves (SP) of plants inoculated with N. parvum 19 and not affected in plants inoculated with other isolates tested (N. parvum 67 or D. seriata 98-1, 99-7, and AR; Fig. 3). The gene
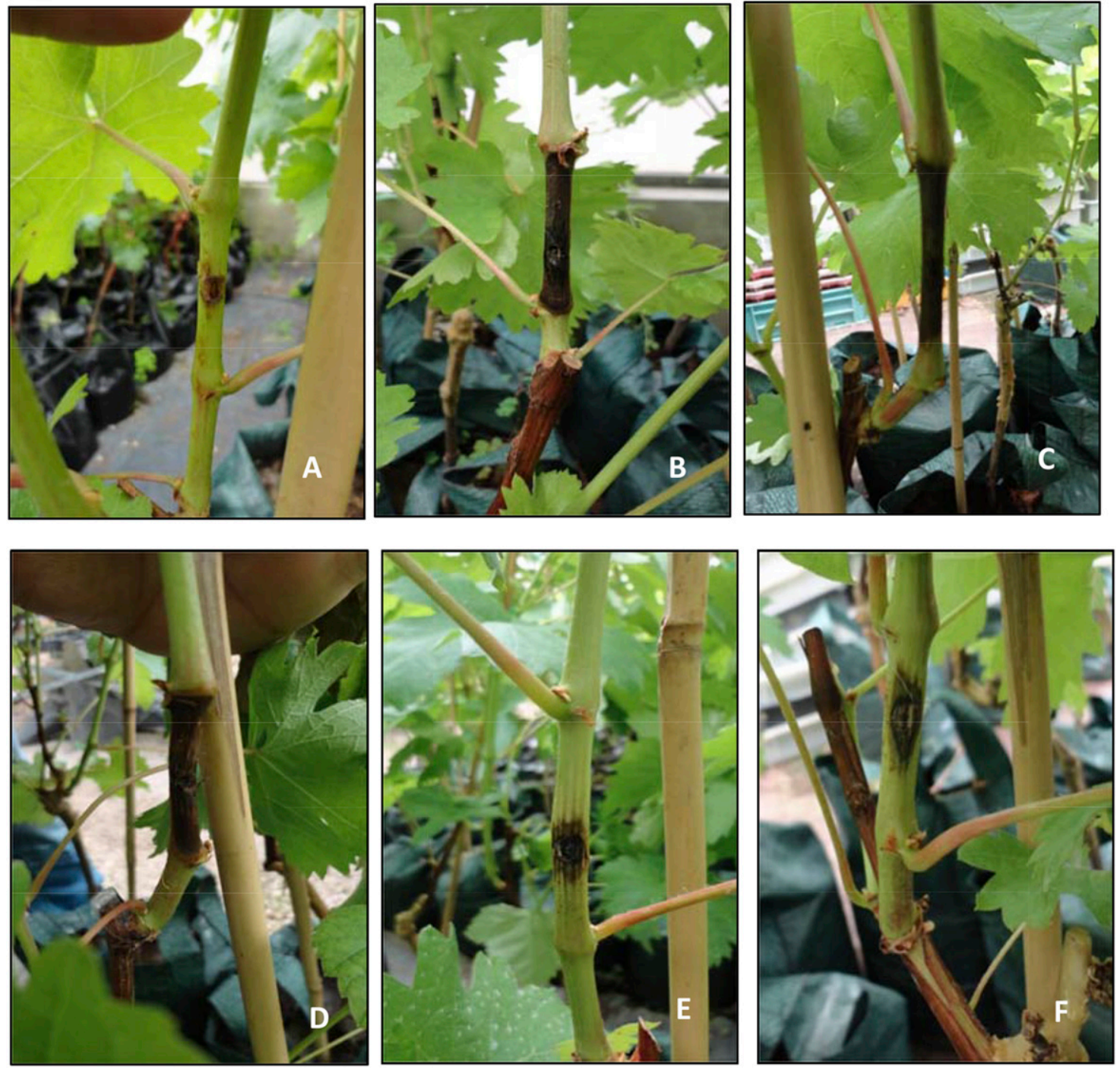

Fig. 1. Lesions observed in the green stems of grafted Aragonez cuttings inoculated with A, control; Neofusicoccum parvum isolates B, 19, C, 67, and C, AR; and Diplodia seriata isolates $\mathrm{E}, 98-1$ and $\mathrm{F}, 99-7$.

Table 3. Dimensions of lesions produced by isolates of Neofusicoccum parvum and Diplodia seriata in green stems, 3 months after inoculation ${ }^{\mathrm{Z}}$

\begin{tabular}{|c|c|c|c|c|c|c|c|c|c|c|c|c|}
\hline \multirow[b]{2}{*}{ Isolates } & \multicolumn{4}{|c|}{ Width $(\mathrm{mm}) \pm \mathrm{SE}$} & \multicolumn{4}{|c|}{ Length $(\mathrm{mm}) \pm \mathrm{SE}$} & \multicolumn{4}{|c|}{ Area $\left(\mathrm{mm}^{2}\right) \pm \mathrm{SE}$} \\
\hline & 2011 & 2012 & 2013 & 2014 & 2011 & 2012 & 2013 & 2014 & 2011 & 2012 & 2013 & 2014 \\
\hline Control & $4.2 \pm 0.5 \mathrm{a}$ & $5.6 \pm 0.8 \mathrm{a}$ & $5.7 \pm 0.7 \mathrm{a}$ & $5.5 \pm 0.7 \mathrm{a}$ & $8.7 \pm 0.5 \mathrm{a}$ & $5.7 \pm 1.0 \mathrm{a}$ & $5.8 \pm 0.9 \mathrm{a}$ & $5.4 \pm 0.8 \mathrm{a}$ & $28.8 \pm 4.2 \mathrm{a}$ & $25.0 \pm 4.6 \mathrm{a}$ & $25.7 \pm 5.0 \mathrm{a}$ & $23.4 \pm 4.9 \mathrm{a}$ \\
\hline \multicolumn{13}{|l|}{ D. seriata } \\
\hline $98-1$ & $7.1 \pm 1.0 \mathrm{ab}$ & $9.1 \pm 1.5 \mathrm{ab}$ & $10.0 \pm 1.6 \mathrm{ab}$ & $9.7 \pm 1.6 \mathrm{~b}$ & $12.8 \pm 2.3 \mathrm{a}$ & $17.5 \pm 5.4 \mathrm{~b}$ & $18.3 \pm 3.3 \mathrm{~b}$ & $19.1 \pm 4.9 \mathrm{~b}$ & $71.5 \pm 17.6 \mathrm{a}$ & $126.3 \pm 50.3 \mathrm{ab}$ & $143.9 \pm 34.5 \mathrm{~b}$ & $145.9 \pm 48.3 \mathrm{~b}$ \\
\hline $99-7$ & nd & $12.8 \pm 1.1 \mathrm{ab}$ & $12.7 \pm 1.0 \mathrm{~b}$ & $13.1 \pm 1.1 \mathrm{~cd}$ & nd & $20.4 \pm 2.9 \mathrm{bc}$ & $19.5 \pm 2.2 \mathrm{~b}$ & $20.1 \pm 2.6 \mathrm{~b}$ & $\mathrm{Nd}$ & $205.9 \pm 34.6 \mathrm{ab}$ & $194.3 \pm 24.6 \mathrm{~b}$ & $206.5 \pm 31.2 \mathrm{c}$ \\
\hline \multicolumn{13}{|l|}{ N. parvum } \\
\hline 19 & $12.8 \pm 1.5 \mathrm{~b}$ & $14.7 \pm 1.7 \mathrm{~b}$ & $15.1 \pm 1.3 \mathrm{c}$ & $14.1 \pm 1.8 \mathrm{~d}$ & $20.4 \pm 3.5 b$ & $24.6 \pm 3.2 \mathrm{c}$ & $25.3 \pm 2.0 \mathrm{c}$ & $24.9 \pm 2.6 \mathrm{c}$ & $203.9 \pm 41.3 \mathrm{ab}$ & $282.7 \pm 48.4 \mathrm{bc}$ & $297.4 \pm 34.2 \mathrm{c}$ & $274.1 \pm 40.0 \mathrm{~d}$ \\
\hline 67 & $28.2 \pm 3.6 \mathrm{c}$ & $24.6 \pm 2.7 \mathrm{c}$ & $24.2 \pm 2.5 \mathrm{~d}$ & $23.4 \pm 2.6 \mathrm{e}$ & $81.3 \pm 5.9 \mathrm{~d}$ & $78.8 \pm 3.1 \mathrm{e}$ & $79.5 \pm 3.2 \mathrm{e}$ & $83.4 \pm 3.8 \mathrm{e}$ & $1793.9 \pm 240.5 \mathrm{c}$ & $1523.1 \pm 165.2 \mathrm{~d}$ & $1508.3 \pm 160.1 \mathrm{e}$ & $1531.7 \pm 168.3 \mathrm{f}$ \\
\hline AR & $9.9 \pm 1.1 \mathrm{ab}$ & $13.8 \pm 1.7 \mathrm{ab}$ & $13.9 \pm 1.6 \mathrm{bc}$ & 12.7 v $1.7 \mathrm{c}$ & $41.3 \pm 1.9 \mathrm{c}$ & $37.8 \pm 2.3 \mathrm{~d}$ & $38.2 \pm 2.6 \mathrm{~d}$ & $39.7 \pm 3.1 \mathrm{~d}$ & $320.8 \pm 42.4 \mathrm{~b}$ & $410.6 \pm 54.3 \mathrm{c}$ & $416.4 \pm 59.9 \mathrm{~d}$ & $394.9 \pm 68.1 \mathrm{e}$ \\
\hline
\end{tabular}

${ }^{\mathrm{z}}$ Data are means $(n=30)$ and columns with the same letter are not significantly different according to Tukey's test $(P<0.05)$. SE $=$ standard error. All log values are back transformed to the original scale (millimeters); nd $=$ not determined. 
expression of $H S P$, regarded as a molecular chaperone, was not affected in leaves of inoculated plants. On the contrary, this gene was upregulated in green stems with AP and SP leaves of plants infected by all five isolates of Botryosphaeriaceae apart from $D$. seriata 99-7, where $H S P$ was upregulated but only in stems with SP leaves (Fig. 4).

Two genes encoding PR proteins were also investigated, a $\beta-1,3-$ glucanase $(G l u c)$ gene and a serine protease inhibitor (PRO) gene. In leaves of plants inoculated with Botryosphaeriaceae fungi, Gluc was generally weakly repressed in AP, while PR6 was generally induced in both AP and SP (Fig. 3). Interestingly, Gluc was upregulated in green stems of plants infected with $N$. parvum and downregulated in plants infected with $D$. seriata, particularly with $D$. seriata 98-1 and 99-7 (Fig. 4). The gene DXS encodes the enzyme 1-deoxy-Dxylulose 5-phosphate synthase, involved in the first major step of terpenoid synthesis, $D X S$ was weakly downregulated in leaves of SP inoculated with $N$. parvum or D. seriata strains. Our results also showed that the expression of the fascAGP gene was repressed in
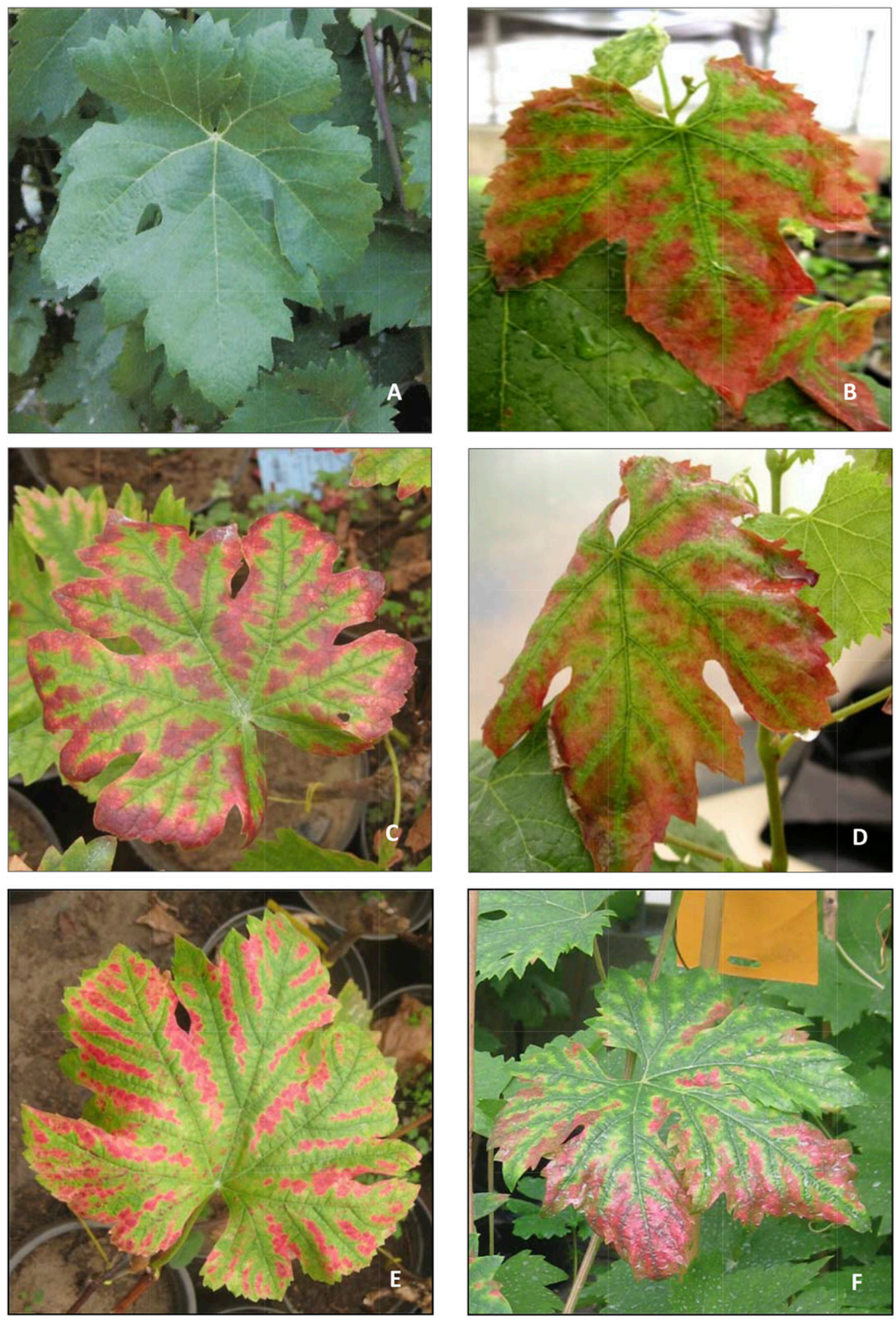

Fig. 2. Foliar symptoms in leaves of grafted Aragonez (= Tempranillo) cuttings inoculated in green stems of A, control; Neofusicoccum parvum isolates B, 19, C, 67, and D, AR; and Diplodia seriata isolates E, 98-1 and F, 99-7. 
green stems of AP and SP infected with N. parvum 67 and AR; both these Botryosphaeriaceae species produced the biggest necroses. The aquaporin PIP2.2 gene was not affected in green stems, whereas it was repressed in AP and SP leaves of plants inoculated with both $N$. parvum and D. seriata 99-7, with a high repression in SP plants.

For genes involved in the phenylpropanoid pathway, the STS gene was weakly upregulated in green stems of grapevine inoculated with

Table 4. Foliar symptoms produced in Aragonez (= Tempranillo) grapevines by isolates of Neofusicoccum parvum and Diplodia seriata 8 months after inoculation

\begin{tabular}{lcccc}
\hline & \multicolumn{4}{c}{ Grapevines with foliar symptoms $(\boldsymbol{\%})^{\mathbf{z}}$} \\
\cline { 2 - 5 } Isolates & $\mathbf{2 0 1 1}$ & $\mathbf{2 0 1 2}$ & $\mathbf{2 0 1 3}$ & $\mathbf{2 0 1 4}$ \\
\hline Control & $0.0 \mathrm{a}$ & $0.0 \mathrm{a}$ & $0.0 \mathrm{a}$ & $0.0 \mathrm{a}$ \\
D. seriata & & & & \\
$\quad$ 99-7 & nd & $33.3 \mathrm{~b}$ & $36.7 \mathrm{~b}$ & $30.0 \mathrm{ab}$ \\
$\quad 98-1$ & $36.7 \mathrm{~b}$ & $50.0 \mathrm{bc}$ & $53.3 \mathrm{bc}$ & $50.0 \mathrm{bc}$ \\
N. parvum & & & & \\
$\quad 19$ & $63.3 \mathrm{bc}$ & $66.7 \mathrm{c}$ & $76.7 \mathrm{c}$ & $73.3 \mathrm{c}$ \\
67 & $76.7 \mathrm{c}$ & $73.3 \mathrm{c}$ & $76.7 \mathrm{c}$ & $73.3 \mathrm{c}$ \\
AR & $6.7 \mathrm{a}$ & $60.0 \mathrm{bc}$ & $56.7 \mathrm{bc}$ & $60.0 \mathrm{bc}$ \\
\hline
\end{tabular}

${ }^{\mathrm{z}}$ Data are percentages $(n=30)$ and columns with the same letter are not significantly different according to Tukey's test $(P<0.05)$. All values are back transformed to percentages; $\mathrm{nd}=$ not determined.
N. parvum 67, 19, and AR (Fig. 4). The second gene involved in this pathway, $P P O$, was tested. $P P O$ was only downregulated in stems (AP and SP) of plants inoculated with $N$. parvum 67 and 19, such as sevenfold for N. parvum 67 (Fig. 4). Moreover, the Lac17 gene, encoding the enzyme that belongs to the group of PPO, was also generally repressed in leaves of $\mathrm{AP}$ and $\mathrm{SP}$, infected by the five isolates of Botryosphaeriaceae tested. For plant metabolites monitored, targeted polyphenolic compounds were quantified, especially transpiceid, transresveratrol, transe-viniferin, transvitisin A, and transvitisin B (Table 6, leaves, and Table 7, green stems). Their distribution was different between leaves and green stems. A high level of transpiceid was observed in leaves in comparison with green stems, whereas transvitisin B was well detected and quantified in green stems and only weakly accumulated in leaves (Tables 6 and 7). A similar pattern was found for transe-viniferin, with a high content in green stems compared with leaves (Tables 6 and 7). This variation may be affected by the developmental stage of green stems. Thus, the sampling of green stems was carried out when lignification began under greenhouse conditions. Moreover, phenolics were significantly accumulated in SP organs of plants inoculated with $D$. seriata strains. Both transresveratrol and trans- $\varepsilon$-viniferin were detected in SP leaves of plants inoculated with D. seriata 99-7 (Table 6). A significant accumulation of transresveratrol and transvitisin B was also observed in SP green stems of plants inoculated with $N$. parvum AR (Table 7), which could correlate with an upregulation of STS in the same samples.

Table 5. Dimensions of lesions produced by isolates of Phyllosctita ampelicida $(\mathrm{Gb})$ and Cladosporium and Penicillium spp. 3 months after inoculation in green stems ${ }^{2}$

\begin{tabular}{|c|c|c|c|}
\hline & Width \pm SE (mm) & Length $\pm \mathrm{SE}(\mathrm{mm})$ & Area $\pm \mathrm{SE}\left(\mathrm{mm}^{2}\right)$ \\
\hline Isolates & 2014 & 2014 & 2014 \\
\hline Control & $5.5 \pm 0.7 \mathrm{a}$ & $5.4 \pm 0.8 \mathrm{a}$ & $23.4 \pm 4.9$ \\
\hline Cladosporium & $5.1 \pm 0.9 \mathrm{a}$ & $5.2 \pm 0.8 \mathrm{a}$ & $20.9 \pm 5.1 \mathrm{a}$ \\
\hline Penicillium & $5.5 \pm 0.8 \mathrm{a}$ & $5.4 \pm 1.0 \mathrm{a}$ & $23.3 \pm 5.3 \mathrm{a}$ \\
\hline Phyllosctita ampelicida (Gb17) & $11.0 \pm 2.2 \mathrm{~b}$ & $16.0 \pm 2.3 \mathrm{~b}$ & $137.4 \pm 33.0 \mathrm{~b}$ \\
\hline P. ampelicida (Gb32) & $11.0 \pm 1.7 \mathrm{~b}$ & $28.0 \pm 2.7 \mathrm{c}$ & $243.6 \pm 48.2 c$ \\
\hline
\end{tabular}

${ }^{\mathrm{z}}$ Data are means $(n=30)$ and columns with the same letter are not significantly different according to Tukey's test $(P<0.05)$. SE $=$ standard error. All log values are back transformed to the original scale (millimeters).

\section{N. parvum}

\begin{tabular}{|c|c|c|c|c|c|}
\hline \multicolumn{2}{|c|}{ Np 19} & \multicolumn{2}{|c|}{ Np 67} & \multicolumn{2}{|c|}{ Np AR } \\
\hline AP & SP & $\mathrm{AP}$ & SP & AP & SP \\
\hline 0.25 & 0.53 & 0.45 & 0.99 & 0.34 & 0.59 \\
\hline 0.80 & 1.00 & 0.61 & 0.68 & 0.95 & 0.86 \\
\hline 1.09 & 1.31 & 1.02 & 1.48 & 1.14 & 1.36 \\
\hline 0.33 & 0.48 & 0.93 & 0.69 & 1.18 & 0.75 \\
\hline 0.63 & 0.96 & 0.82 & 1.17 & 0.58 & 1.27 \\
\hline 0.57 & 0.72 & 0.45 & 0.48 & 0.77 & 0.39 \\
\hline 0.19 & 0.65 & 0.32 & 0.68 & 0.09 & 0.54 \\
\hline 2.61 & 27.69 & 6.70 & 35.08 & 2.29 & 16.26 \\
\hline 0.49 & 0.35 & 0.44 & 0.22 & 0.55 & 0.21 \\
\hline 0.27 & 0.21 & 0.08 & 0.13 & 0.11 & 0.06 \\
\hline
\end{tabular}

\section{D. seriata}

\begin{tabular}{|c|c|c|c|}
\hline \multicolumn{2}{|c|}{ Ds 98-1 } & \multicolumn{2}{|c|}{ Ds 99-7 } \\
\hline AP & SP & AP & SP \\
\hline 0.26 & 1.01 & 0.60 & 0.87 \\
\hline 0.65 & 0.79 & 0.93 & 0.79 \\
\hline 0.97 & 0.90 & 1.35 & 1.11 \\
\hline 0.79 & 1.00 & 0.52 & 0.71 \\
\hline 0.71 & 1.24 & 0.78 & 1.39 \\
\hline 0.77 & 0.51 & 0.72 & 0.38 \\
\hline 0.07 & 0.25 & 0.64 & 0.40 \\
\hline 4.03 & 14.90 & 1.62 & 18.87 \\
\hline 0.56 & 0.58 & 0.33 & 0.17 \\
\hline 0.05 & 0.11 & 0.16 & 0.01 \\
\hline
\end{tabular}

Fig. 3. Relative expression of 10 selected genes in the leaves of asymptomatic (AP) and symptomatic plants (SP) inoculated with three Neofusicoccum parvum isolates (Np 19 , $\mathrm{Np} \mathrm{67}$, and Np AR) and two Diplodia seriata isolates (Ds 98-1 and Ds 99-7). The color scale represents the ratio values corresponding to the mean of two or three independent experiments. Genes down- or over-expressed appear in shades of gray, with expression level lower or higher $(<0.1$ and $>30$, respectively); and in white, no change in gene expression compared to the control. Gene changes in relative expression were $>2 x$ or $<0.5 x$, respectively. 


\section{Discussion}

This study is the first to report the reproduction of foliar symptoms after artificial infection of grapevines with Botryosphaeriaceae species as described for E. lata and the reproduction of Eutypa dieback (Camps et al. 2010; Péros and Berger 1994). Pathogenicity trials with Botryosphaeriaceae species have already been conducted but only lesions at the initial inoculation point were described and no foliar symptoms were developed (Taylor et al. 2005; Úrbez-Torres and Gubler 2009). In our study, lesion sizes and expression of foliar symptoms differed according to the fungal strains inoculated. Pathogenicity experiments showed that isolates $N$. parvum 67 and AR produced longer lesions with greater surface area than isolates D. seriata $98-1$ and 99-7 and N. parvum 19. Furthermore, in plants inoculated with $N$. parvum isolates, the percentage of infected plants displaying foliar symptoms was more than $50 \%$ and could reach $73 \%$.

According to Úrbez-Torres (2011), Botryosphaeriaceae species that infect grapevines can be divided into three different groups based on aggressiveness rankings (high, moderate, or low), where Neofusicoccum spp. belong to the highly aggressive group and Diplodia spp. belong to the moderately aggressive group. In pathogenicity tests on grapevine green stems ('Mourvèdre') inoculated with $N$. parvum or D. seriata, Spagnolo et al. (2014a) showed that mean lesion lengths differed significantly between $N$. parvum and $D$. seriata isolates. Lesions associated with $N$. parvum infection were $39.6 \pm 9.1 \mathrm{~mm}$ long, while those associated with $D$. seriata infection

\section{N. parvum}

\begin{tabular}{|c|c|c|c|c|c|}
\hline \multicolumn{2}{|c|}{ Np 19} & \multicolumn{2}{|c|}{ Np 67} & \multicolumn{2}{|c|}{ Np AR } \\
\hline AP & SP & AP & SP & AP & SP \\
\hline 0.33 & 0.57 & 0.48 & 0.86 & 0.31 & 0.44 \\
\hline 0.78 & 1.21 & 1.38 & 1.18 & 1.03 & 0.94 \\
\hline 1.06 & 1.40 & 3.20 & 1.66 & 1.04 & 1.79 \\
\hline 0.94 & 1.03 & 1.31 & 1.16 & 1.09 & 0.77 \\
\hline 6.32 & 5.40 & 31.68 & 11.14 & 6.93 & 21.98 \\
\hline 3.45 & 12.69 & 1.38 & 4.80 & 1.59 & 1.70 \\
\hline 0.44 & 0.34 & 0.26 & 0.68 & 0.10 & 0.14 \\
\hline 0.82 & 0.80 & 0.61 & 1.03 & 0.70 & 0.59 \\
\hline 1.90 & 3.01 & 1.70 & 2.61 & 1.49 & 2.98 \\
\hline 0.13 & 0.14 & 0.50 & 0.28 & 1.59 & 1.71 \\
\hline
\end{tabular}

\section{D. seriata}

\begin{tabular}{|c|c|c|c|}
\hline \multicolumn{2}{|c|}{ Ds 98-1 } & \multicolumn{2}{|c|}{ Ds 99-7 } \\
\hline AP & SP & AP & SP \\
\hline 0.64 & 0.19 & 0.71 & 0.44 \\
\hline 0.87 & 0.65 & 0.75 & 0.68 \\
\hline 1.03 & 1.21 & 1.10 & 0.99 \\
\hline 1.78 & 1.30 & 1.26 & 1.09 \\
\hline 7.98 & 10.77 & 1.23 & 4.87 \\
\hline 0.91 & 0.06 & 2.20 & 0.35 \\
\hline 1.09 & 0.66 & 0.98 & 0.76 \\
\hline 0.67 & 0.61 & 0.74 & 0.64 \\
\hline 1.79 & 0.69 & 1.00 & 0.80 \\
\hline 1.29 & 0.90 & 0.51 & 1.05 \\
\hline
\end{tabular}

Fig. 4. Relative expression of 10 selected genes in the green stems of asymptomatic (AP) and symptomatic plants (SP) inoculated with three Neofusicoccum parvum isolates (Np 19, Np 67, and Np AR) and with two Diplodia seriata isolates (Ds 98-1 and Ds 99-7). The color scale represents the ratio values corresponding to the mean of two or three independent experiments. Genes down- or over-expressed appear in shades of gray, with expression level lower or higher $(<0.1$ and $>30$, respectively); and in white, no change in gene expression compared to the control. Gene changes in relative expression were $>2 x$ or $<0.5 x$, respectively.

Table 6. Stilbenic compound contents in leaves of control plants in asymptomatic (AP) and symptomatic (SP) leaves of plants inoculated with three Neofusicoccum parvum isolates (19, 67, and AR) and with Diplodia seriata isolates (98-1 and 99-7)

\begin{tabular}{|c|c|c|c|c|c|c|c|c|c|c|c|}
\hline \multirow[b]{3}{*}{ Stilbenes } & \multicolumn{11}{|c|}{ Contents $\left(\mu \mathrm{g} \mathrm{g}^{-1} \mathrm{FW}\right)^{\mathrm{Z}}$} \\
\hline & \multirow[b]{2}{*}{ Control } & \multicolumn{2}{|c|}{ N. parvum 19} & \multicolumn{2}{|c|}{ N. parvum 67} & \multicolumn{2}{|c|}{ N. parvum AR } & \multicolumn{2}{|c|}{ D. seriata 98-1 } & \multicolumn{2}{|c|}{ D. seriata 99-7 } \\
\hline & & $\mathbf{A P}$ & SP & AP & SP & AP & SP & AP & SP & AP & SP \\
\hline transpiceid & $202.0 \pm 46.0$ & $200.0 \pm 5.0$ & $253.0 \pm 53.0$ & $233.0 \pm 51.0$ & $240.0 \pm 41.0$ & $205.0 \pm 19.0$ & $265.0 \pm 24.0$ & $228.0 \pm 75.0$ & $201.0 \pm 45.0$ & $347.0 \pm 68.0$ & $291.0 \pm 57.0$ \\
\hline transresveratrol & $3.0 \pm 0.0$ & $12.0 \pm 5.0$ & $12.0 \pm 6.0$ & $3.0 \pm 2.0$ & $11.0 \pm 2.0$ & $13.0 \pm 11.0$ & $7.0 \pm 2.0$ & $4.0 \pm 1.0$ & $11.0 \pm 4.0$ & $9.0 \pm 2.0$ & $30.0 \pm 17.0^{*}$ \\
\hline transe-viniferin & $7.0 \pm 1.0$ & $7.0 \pm 4.0$ & $18.0 \pm 9.0$ & $16.0 \pm 3.0$ & $15.0 \pm 1.0$ & $7.0 \pm 1.0$ & $17.0 \pm 12.0$ & $11.0 \pm 2.0$ & $17.0 \pm 5.0$ & $29.0 \pm 17.0$ & $33.0 \pm 11.0^{*}$ \\
\hline transvitisin A & $5.0 \pm 1.0$ & nd & $6.0 \pm 3.0$ & $5.0 \pm 2.0$ & $7.0 \pm 0.0$ & $3.0 \pm 1.0$ & $6.0 \pm 2.0$ & $1.0 \pm 1.0$ & $6.0 \pm 4.0$ & $5.0 \pm 1.0$ & $6.0 \pm 3.0$ \\
\hline transvitisin B & $5.0 \pm 1.0$ & nd & nd & nd & $3.0 \pm 3.0$ & nd & nd & $1.0 \pm 1.0$ & nd & $2.0 \pm 2.0$ & nd \\
\hline
\end{tabular}

z Values followed by an asterisk are significantly different to the control value (Dunn's Multiple Comparison Test, $P \leq 0.05$ ); nd indicates compounds not detected.

Table 7. Stilbenic compound contents in green stems of control plant in asymptomatic (AP) and symptomatic (SP) green stems of plants inoculated with three Neofusicoccum parvum isolates (19, 67, and AR) and two Diplodia seriata isolates (98-1 and 99-7)

\begin{tabular}{|c|c|c|c|c|c|c|c|c|c|c|c|}
\hline \multirow[b]{3}{*}{ Stilbenes } & \multicolumn{11}{|c|}{ Contents $\left(\mu \mathrm{g} \mathrm{g}^{-1} \mathrm{FW}\right)^{\mathrm{Z}}$} \\
\hline & \multirow[b]{2}{*}{ Control } & \multicolumn{2}{|c|}{ N. parvum 19} & \multicolumn{2}{|c|}{ N. parvum 67} & \multicolumn{2}{|c|}{ N. parvum AR } & \multicolumn{2}{|c|}{ D. seriata $98-1$} & \multicolumn{2}{|c|}{ D. seriata $99-7$} \\
\hline & & $\mathbf{A P}$ & SP & $\mathbf{A P}$ & SP & $\mathbf{A P}$ & SP & $\mathbf{A P}$ & SP & $\mathbf{A P}$ & SP \\
\hline transpiceid & nd & nd & $11.0 \pm 10.0$ & $0.021 \pm 0.003$ & nd & $39.0 \pm 6.0$ & nd & $1.0 \pm 1.0$ & $26.0 \pm 7.0$ & nd & nd \\
\hline transresveratrol & nd & $31.0 \pm 12.0$ & $30.0 \pm 5.0$ & $51.0 \pm 2.0$ & $22.0 \pm 6.0$ & nd & $87.0 \pm 19.0^{*}$ & $28.0 \pm 10.0$ & $67.0 \pm 18.0$ & nd & nd \\
\hline transe-viniferin & $13.0 \pm 2.0$ & $840.0 \pm 386.0$ & $907.0 \pm 159.0$ & $1615.0 \pm 265.0$ & $863.0 \pm 267.0$ & $2847.0 \pm 503.0$ & $1387.0 \pm 404.0$ & $785.0 \pm 251.0$ & $1188.0 \pm 341.0$ & $510.0 \pm 36.0$ & $146.0 \pm 24.0$ \\
\hline transvitisin A & nd & nd & $12.0 \pm 11.0$ & $166.0 \pm 37.0$ & $32.0 \pm 9.0$ & $195.0 \pm 61.0$ & nd & $34.0 \pm 19.0$ & $41.0 \pm 13.0$ & nd & nd \\
\hline transvitisin B & nd & $120.0 \pm 82.0$ & $174.0 \pm 58.0$ & $258 \pm 35.0$ & $150.0 \pm 31.0$ & $919.0 \pm 14.0$ & $263.0 \pm 6.0^{*}$ & $115.0 \pm 65.0$ & $383.0 \pm 112.0$ & $78.0 \pm 21.0$ & nd \\
\hline
\end{tabular}

z Values followed by an asterisk are significantly different to the control value (Dunn's Multiple Comparison Test, $P \leq 0.05$ ); nd indicates compounds not detected. 
were $14.3 \pm 3.9 \mathrm{~mm}$. Moreover, the largest lesions were recorded at the onset of flowering whereas, at separated clusters ( $\mathrm{G}$ stage) and veraison, no significant differences between the fungi could be detected. These results reveal that the development of lesions may be influenced by aggressiveness of the fungal strain as well as plant phenological stage (Spagnolo et al. 2014b).

Production of phytotoxic metabolites by Botryosphaeriaceae species has been reported by Martos et al. (2008), Andolfi et al. (2011), and Abou-Mansour et al. (2015). Ramírez-Suero et al. (2014) reported necrosis that appeared in calli of 'Chardonnay' subcultured on media containing extracellular metabolites produced by different isolates of $N$. parvum and $D$. seriata. The metabolites produced by $N$. parvum Bourgogne S-116 caused total necrosis of calli whereas metabolites from both isolates $D$. seriata 98.1 and 99.7 induced only partial necrosis. These results are also in agreement with those obtained by Martos et al. (2008), who found a greater phytotoxic activity on Aragonez grapevine leaves treated with culture filtrates from $N$. parvum compared with $D$. seriata. These results confirm that $N$. parvum isolates are more virulent than those of $D$. seriata. Moreover, studies from different countries reported differential susceptibility to wood necrosis caused by Botryosphaeriaceae fungi (Amponsah et al. 2011; Guan et al. 2016; Taylor et al. 2005). Further work needs to be carried out to elucidate the mechanisms of the susceptibility in various cultivars in terms of plant immunity and phytotoxic activity of fungi.

The response of plants to infection and emergence of foliar symptoms were studied in terms of the genes involved in detoxification and stress tolerance. Thus, no modifications of GST5, epoxHF, or epoxH2 expression were detected under the conditions tested in this study. In contrast, Spagnolo et al. (2012) showed that these genes were upregulated in leaves and stems of grapevine affected by GTD in the vineyard. It has been demonstrated that several toxins produced by GTD agents contain epoxides (Abou-Mansour et al. 2015; Andolfi et al. 2011), and detoxification enzymes have been hypothesized to have a role in the detoxification of these compounds or their active derived compounds metabolized in grapevines (AbouMansour et al. 2015; Spagnolo et al. 2014a). A weak repression of $S O D$ was observed in leaves of plants inoculated with $N$. parvum 19 and D. seriata 99-7. A similar trend was reported in AP leaves and green stems of apoplectic plants and those affected by esca proper (Letousey et al. 2010; Magnin-Robert et al. 2011; Spagnolo et al. 2012). These results suggest that important downregulation of $S O D$ occurs before symptoms appear on the plant. Repression of $S O D$ could indicate a lack of oxidative stress control, which could be lethal for plants (Letousey et al. 2010). Similar to previous studies, where an increased abundance of HSP was reported in both green stems of field-grown plants artificially infected with $N$. parvum and D. seriata (Spagnolo et al. 2014b) and grapevine affected by esca proper and apoplexy (Spagnolo et al. 2012), an upregulation of $H S P$ was detected in green stems of plants inoculated with the five Botryosphaeriaceae isolates. HSP function by binding partially denatured proteins to prevent irreversible protein inactivation and aggregation (Waters 1995) and could be an indicator of a plant tolerant state.

To compare defense responses of plants inoculated by $N$. parvum and $D$. seriata isolates, we targeted the most frequently observed and the best-characterized active defense mechanisms in grapevine; namely, the phenylpropanoid pathway. STS expression was induced in green stems of vines inoculated with the three $N$. parvum isolates. These three fungi were previously described as inducing the largest lesion sizes (surface and length). In addition to STS upregulation, only the SP green stems of plants inoculated with $N$. parvum AR showed significant accumulation of transresveratrol. Various studies have also described an upregulation of STS in the leaves of fieldgrown grapevines affected by GTD (Letousey et al. 2010; MagninRobert et al. 2011). Moreover, Ramírez-Suero et al. (2014) showed that extracellular compounds produced by $N$. parvum and $D$. seriata induce the expression of STS in Chardonnay calli. All these data suggest that the STS gene could be a good marker of stress responses, such as oxidant stress. In this sense, stilbenic polyphenols are also able to scavenge reactive oxygen species and, thus, protect the plant cells from oxidative stresses after pathogen attack (Bertsch et al. 2013). Another targeted gene, $P P O$, shown to be involved in plant resistance (Thipyapong et al. 2007) was downregulated only in stems of plants inoculated with $N$. parvum isolates, thus inducing larger cankers. Moreover, a repression of Lac17 expression was observed in leaves of plants inoculated with $N$. parvum and D. seriata strains. These results suggest that GTD fungal agents induce strong perturbations of PPO. Regarding the absence of variation in stilbenoids and the repression of $P P O$ expression in plants inoculated with $N$. parvum strains, another group of phenolics may be affected such as flavonoids or lignin precursors. Along the same lines, Lima et al. (2010) reported an accumulation of quercetin-3-Oglucoside and caffeic acid in healthy leaves of the AP cordons of esca-affected plants and a decrease in the same compounds in diseased leaves.

Regarding PR protein expression, an upregulation of PR6 was observed in leaves in response to infection with species of Botryosphaeriaceae. These observations are in accordance with previous studies showing modulation of PR protein (PR6, chitinase, and $\beta$-1,3-glucanase) expression in leaves, green stems, and wood of vines affected by GTD (Camps et al. 2010; Fontaine et al. 2015; Letousey et al. 2010; Magnin-Robert et al. 2011; Spagnolo et al. 2012, 2014b; Valtaud et al. 2009). Altogether, these data may indicate that $P R 6$ plays a defensive role during the response of grapevines to GTD fungal agents. The fascAGP genes belong to the large family of hydroxyproline-rich glycoprotein proteins, which are thought to accumulate in response to elicitor molecules released by fungi and to play a role in plant defense responses (Agrios 2005). Our results showed an alteration of fascAGP expression, which suggests its possible role as a marker of stress responses triggered by GTD agents. Meanwhile, expression of PIP2.2, encoding a membrane water channel playing a role in controlling the water content of cells, was repressed by fungal infection only in leaves, as previously reported in leaves of field-grown vines affected by apoplexy events (Letousey et al. 2010). It seems that GTD may perceive a water stress signal only in the later steps of the disease and that the appearance of symptoms cannot be simply considered as a water transportdeficit-inducing disease but that other physiological mechanisms may be involved (Christen et al. 2007).

In conclusion. Our study shows that 1 -year-old vines infected with Botryosphaeriaceae species D. seriata and $N$. parvum induce lesions on the stem and expression of foliar symptoms. This is the first time that the reproduction of foliar symptoms with both species is reported, with a frequency reaching $77 \%$ and a value close to those observed in the vineyard. In addition, because the responses of artificially infected plants show similarities to those observed in plants naturally infected in the vineyard, this simple model system could be useful in future studies aimed at determining the relationship between fungi and the appearance of foliar symptoms, especially in a chronic form, and to test ecofriendly strategies to manage Botryosphaeria dieback. Among the gene expressions studied and the phenolics found, some could be selected as markers for the emergence of disease such as SOD, STS, fascAGP, and flavonoids. Further work will be aimed at quantifying phytotoxic compounds reported from D. seriata and $N$. parvum (Abou-Mansour et al. 2015; Djoukeng et al. 2009; Evidente et al. 2010) such as dihydroisocoumarin and epoxytoluquinol derivatives on leaves and green stems to better appreciate the molecular dialogue between fungi and plants, because these fungi have never been detected in leaves.

\section{Acknowledgments}

This research was financed by the French government Compte d'Affectation Spéciale au Développement Agricole et Rural V903 and V1301, the ChampagneArdenne Region, and the national program France Agrimer, and was also supported by the European COST Action FA1303 "Sustainable control of grapevine trunk diseases". We thank P. Larignon for providing Diplodia seriata strains; P. Alan, a native speaker and researcher at the University Nova of Lisboa, Portugal; and B. Antony, researcher at the University of Fribourg, Switzerland, for revising the English of this manuscript. 


\section{Literature Cited}

Abou-Mansour, E., Débieux, J., Ramírez-Suero, M., Bénard-Gellon, M., MagninRobert, M., Spagnolo, A., Chong, J., Farine, S., Bertsch, C., L'Haridon, F., Serrano, M., Fontaine, F., Rego, C., and Larignon, P. 2015. Phytotoxic metabolites from Neofusicoccum parvum, a pathogen of Botryosphaeria dieback of grapevine. Phytochemistry 115:207-215.

Agrios, G. N. 2005. Plant Pathology. Academic Press, San Diego, CA.

Amponsah, N. T., Jones, E. E., Ridgway, H. J., and Jaspers, M. V. 2011. Identification, potential inoculum sources and pathogenicity of botryosphaeriaceous species associated with grapevine dieback disease in New Zealand. Eur. J. Plant Pathol. 131:467-482.

Andolfi, L., Mugnai, L., Luque, J., Surico, G., Cimmino, A., and Evidente, A. 2011. Phytotoxins produced by fungi associated with grapevine trunk diseases. Toxins (Basel) 3:1569-605.

Bertsch, C., Ramírez-Suero, M., Magnin-Robert, M., Larignon, P., Chong, J., Abou-Mansour, E., Spagnolo, A., Clément, C., and Fontaine, F. 2013. Trunk diseases of grapevine: Complex and still poorly. Plant Pathol. 62:243-265.

Bézier, A., Lambert, B., and Baillieul, F. 2002. Study of defense-related gene expression in grapevine leaves and berries infected with Botrytis cinerea. Eur. J. Plant Pathol. 108:111-120.

Bruez, E., Lecomte, P., Grosman, J., Doublet, B., Bertsch, C., Fontaine, F., Da Costa, J. P., Ugaglia, A., Teissedre, P. L., Guerin-Dubrana, L., and Rey, P. 2013. Overview of grapevine trunk diseases in France in the early 2000s. Phytopathol. Mediterr. 52:262-275.

Camps, C., Kappel, C., Lecomte, P., Léon, C., Gomès, E., Coutos-Thévenot, P., and Delrot, S. 2010. A transcriptomic study of grapevine (Vitis vinifera cv. Cabernet-Sauvignon) interaction with the vascular ascomycete fungus Eutypa lata. J. Exp. Bot. 61:1719-1737.

Castillo-Pando, M., Sommers, A., Green, C. D., Priest, M., and Sriskanthades, M. 2001. Fungi associated with dieback of Semillon grapevines in the Hunter Valley of New South Wales. Australas. Plant Pathol. 30:59-63.

Chiarappa, L. 2000. Esca (black measles) of grapevine. An overview. Phytopathol. Mediterr. 39:11-15.

Christen, D., Schonmann, S., Jermini, M., Strasser, R. J., and Defago, G. 2007. Characterization and early detection of grapevine (Vitis vinifera) stress responses to esca disease in situ chlorophyll fluorescence and comparison with drought stress. Environ. Exp. Bot. 60:504-514.

Cristinzio, G. 1978. Gravil attachi di Botryosphaeria obtusa su vite provincial di Insernia. Inf. Fitopatol. 6:21-23.

Crous, P. W., Slippers, M. J., Rheeder, J., Marasas, W. F. O., Phillips, A. J. L., Alves, A., Burgess, T., Barber, P., and Groenewald, J. Z. 2006. Phylogenetic lineages in the Botryosphaeriaceae. Stud. Mycol. 55:235-253.

Djoukeng, J. D., Polli, S., Larignon, P., and Abou-Mansour, E. 2009. Identification of phytotoxins from Botryosphaeria obtusa, a pathogen of black dead arm disease of grapevine. Eur. J. Plant Pathol. 124:303-308.

Evidente, A., Punzo, B., Andolfi, A., Cimmino, A., Melck, D., and Luque, J. 2010. Lipophilic phytotoxins produced by Neofusicoccum parvum, a grapevine canker agent. Phytopathol. Mediterr. 49:74-79.

Fischer, M. 2006. Biodiversity and geographic distribution of Basidiomycetes causing esca-associates white rot in grapevine: A worldwide perspective. Phytopathol. Mediterr. 45:S30-S42.

Fontaine, F., Pinto, C., Vallet, J., Clément, C., Gomes, A., and Spagnolo, A. 2015. The effects of Grapevine Trunk Diseases (GTDs) on vine physiology. Online publication. Eur. J. Plant Pathol. doi:10.1007/s10658-015-0770-0

Gerbore, J. 2013. Lutte biologique contre un champignon pathogène impliqué dans l'esca de la vigne, par utilisation de l'oomycète Pythium oligandrum. $\mathrm{PhD}$ thesis, Université de Pau et des Pays de l'Adour.

Gerbore, J., Benhamou, N., Vallance, J., Le Floch, G., Grizard, D., Regnault-Roger, C., and Rey, P. 2013. Biological control of plant pathogens: Advantages and limitations seen through the case study of Pythium oligandrum. Environ. Sci. Pollut. Res. 21: $4847-4860$

Graniti, A., Surico, G., and Mugnai, L. 2000. Esca of grapevine: A disease complex or a complex of diseases? Phytopathol. Mediterr. 39:16-20.

Grosman, J., and Doublet, B. 2012. Maladies du bois de la vigne. Synthèse des dispositifs d'observation au vignoble, de l'observatoire 2003-2008 au réseau d'epidémio-surveillance actuel. Phytoma 651:31-35.

Guan, X., Essakhi, S., Laloue, H., Nick, P., Bertsch, C., and Chong, J. 2016. Mining new resources for grape resistance against Botryosphaeriaceae: A focus on Vitis vinifera ssp. sylvestris. Plant Pathol. 65:273-284.

Larignon, P., and Dubos, B. 1997. Fungi associated with esca disease in grapevine. Eur. J. Plant Pathol. 103:147-157.

Larignon, P., Fontaine, F., Farine, S., Clément, C., and Bertsch, C. 2009. Esca et Black Dead Arm: Deux acteurs majeurs des maladies du bois chez la vigne. C. R. Biol. 332:765-783.

Larignon, P., Fulchic, R., Laurent, C., and Dubos, B. 2001. Observation of black dead arm in French vineyards. Phytopathol. Mediterr. 40:S336-S342.

Larignon, P., Spagnolo, A., Bertsch, C., and Fontaine, F. 2015. First report of young grapevine decline caused by Neofusicoccum parvum in France. Plant Dis. 99:1859.
Letousey, P., Baillieul, F., Perrot, G., Rabenoelina, F., Boulay, M., Valliant-Gaveau, N. Clément, C., and Fontaine, F. 2010. Early events prior to visual symptoms in the apoplectic form of grapevine esca disease. Phytopathology 100:424-431.

Lima, M. R. M., Felgueiras, M. L., Graça, G., Rodrigues, J. E. A., Barros, A., Gil, A. M., and Dias, A. C. P. 2010. NMR metabolomics of esca-disease-affected Vitis vinifera cv. Alvarinho leaves. J. Exp. Bot. 61:4033-4042.

Magnin-Robert, M., Letousey, P., Spagnolo, A., Rabenoelina, F., Jacquens, L., Mercier, L., Clément, C., and Fontaine, F. 2011. Leaf stripe form of esca induces alteration of photosynthesis and defence reactions in presymptomatic leaves. Funct. Plant Biol. 38:856-866.

Martos, S., Andolfi, A., Luque, J., Mugnai, L., Surico, G., and Evidente, A. 2008. Production of phytotoxic metabolites by five species of Botryosphaeriaceae causing decline on grapevines, with special interest in the species Neofusicoccum luteum and N. parvum. Eur. J. Plant Pathol. 121:451-461.

Moller, W. J., and Kasimatis, A. N. 1978. Dieback of grapevines caused by Eutypa armeniacae. Plant Dis. Rep. 62:254-258.

Péros, J. P., and Berger, G. 1994. A rapid method to assess the aggressiveness of Eutypa lata isolates and the susceptibility of grapevine cultivar to Eutypa dieback. Agronomie 14:515-523.

Péros, J. P., and Berger, G. 1999. Diversity within natural progenies of the grapevine dieback fungus Eutypa dieback. Curr. Genet. 36:301-309.

Petzoldt, C. H., Moller, W. J., and Sall, M. A. 1981. Eutypa dieback of grapevines: Seasonal differences in infection and duration of susceptibility of pruning wounds. Phytopathology 71:540-543.

Phillips, A. J. L., Crous, P. W., and Alves, A. 2007. Diplodia seriata, the anamorph of "Botryosphaeria" obtusa. Fungal Divers. 25:141-155.

Pierron, R. J. G., Pages, M., Couderc, C., Compant, S., Jacques, A., and Violleau, F. 2015. In vitro and in planta fungicide properties of ozonated water against the esca-associated fungus Phaeoacremonium aleophilum. Sci. Hortic. (Amsterdam) 189:184-191.

Ramírez-Suero, M., Bénard-Gellon, M., Chong, J., Laloue, H., Stempien, E., Abou-Mansour, E., Fontaine, F., Larignon, P., Mazket-Kieffer, F., Farine, S., and Bertsch, C. 2014. Extracellular compounds produced by fungi associated with Botryosphaeria dieback induce differential defense gene expression patterns and necrosis in Vitis vinifera cv. Chardonnay cells. Protoplasma 251:1417-1426.

Rego, C., Nascimento, T., Cabral, A., Silva, M. J., and Oliveira, H. 2009. Control of grapevine wood fungi in commercial nurseries. Phytopathol. Mediterr. 48:128-135.

Rovesti, L., and Montermini, A. 1987. Un deprimento della vitte causato de Sphaeropsis malorum in provincia di Reggio Emilia. Inf. Fitopatol. 1:59-61.

Savocchia, S., Steel, C. C., Stodart, B. J., and Somers, A. 2007. Pathogenicity of Botryosphaeria species from declining grapevines in sub tropical of Eastern Australia. Vitis 46:27-32.

Sosnowski, M. R., Lardner, R., Wicks, T. J., and Scott, E. S. 2007. The influence of grapevine cultivar and isolate of Eutypa lata on wood and foliar symptoms. Plant Dis. 91:924-931.

Spagnolo, A., Larignon, P., Magnin-Robert, M., Hovasse, A., Cilindre, C., Van Dorsselaer, A., Clément, C., Schaffer-Reiss, C., and Fontaine, F. 2014a. Flowering as the most highly sensitive period of grapevine (Vitis vinifera cv. Mourvèdre) to the Botryosphaeria dieback agents of Neofusicoccum parvum and Diplodia seriata infection. Int. J. Mol. Sci. 15:9644-9669.

Spagnolo, A., Magnin-Robert, M., Alayi, T. D., Cilindre, C., Mercier, L. Schaeffer-Reiss, C., Van Dorsselaer, A., Clément, C., and Fontaine, F. 2012. Physiological changes in green stems of Vitis vinifera L. cv. Chardonnay in response to esca proper and apoplexy revealed by proteomic and transcriptomic analyses. J. Proteome Res. 11:461-475.

Spagnolo, A., Magnin-Robert, M., Alayi, T. D., Cilindre, C., Schaeffer-Reiss, C., Van Dorsselaer, A., Clément, C., Larignon, P., Ramírez-Suero, M., Chong, J., Bertsch, C., Abou-Mansour, E., and Fontaine, F. 2014b. Differential responses of three grapevine cultivars to Botryosphaeria dieback. Phytopathology 104:1021-1035.

Taylor, A., Hardy, G. E., St, J., Wood, P., and Burgess, T. 2005. Identification and pathogenicity of Botryosphaeria species associated with grapevine decline in Western Australia. Australas. Plant Pathol. 34:187-95.

Thipyapong, P., Stout, M. J., and Attajarusit, J. 2007. Functional analysis of polyphenol oxidases by antisense/sense technology. Molecules 12:1569-1595.

Úrbez-Torres, J. R. 2011. The status of Botryophaeriaceae species infecting grapevines. Phytopathol. Mediterr. 50:S5-S45.

Úrbez-Torres, J. R., and Gubler, W. D. 2009. Pathogenicity of Botryosphaeria species isolated from grapevine cankers in California. Plant Dis. 93:584-92.

Úrbez-Torres, J. R., Leavitt, G. M., Guerrero, J. C., Guevara, J., and Gubler, W. D. 2008. Identification and pathogenicity of Lasiodiplodia theobromae and Diplodia seriata, the causal agents of bot canker disease of grapevines in Mexico. Plant Dis. 92:519-529.

Valtaud, C., Larignon, P., Roblin, G., and Fleurat-Lessard, P. 2009. Development and ultrastructural features of Phaeomoniella chlamydospora and Phaeoacremonium aleophilum in relation to xylem degradation in esca disease of the grapevine. J. Plant Pathol. 91:37-51.

Waters, E. R. 1995. The molecular evolution of the small heat-shock proteins in plants. Genetics 141:785-795. 